Agroforestry, livestock, fodder production and climate change adaptation and mitigation in East Africa: issues and options

Ian K Dawson, Sammy Carsan, Steve Franzel, Roeland Kindt, Paulo van Breugel, Lars Graudal, Jens-Peter B Lillesø, Caleb Orwa, Ramni Jamnadass 


\section{Agroforestry, livestock, fodder production and climate change adaptation and mitigation in East Africa: issues and options}

Ian K Dawson, Sammy Carsan, Steve Franzel, Roeland Kindt, Paulo van Breugel, Lars Graudal, Jens-Peter B Lillesø, Caleb Orwa, Ramni Jamnadass 
Correct citation: Dawson IK, Carsan S, Franzel S, Kindt R, van Breugel P, Graudal L, Lillesø J-PB, Orwa C, Jamnadass R. 2014. Agroforestry, livestock, fodder production and climate change adaptation and mitigation in East Africa: issues and options. ICRAF Working Paper No. 178. Nairobi, World Agroforestry Centre. DOI: http://dx.doi.org/10.5716/WP14050.PDF

Titles in the Working Paper Series aim to disseminate interim results on agroforestry research and practices and stimulate feedback from the scientific community. Other publication series from the World Agroforestry Centre include: Technical Manuals, Occasional Papers and the Trees for Change Series.

Published by the World Agroforestry Centre

United Nations Avenue

PO Box 30677, GPO 00100

Nairobi, Kenya

Tel: +254(0)20 722 4000, via USA +1 6508336645

Fax: +254(0)20 722 4001, via USA +1 6508336646

Email: worldagroforestry@cgiar.org

Website: www.worldagroforestry.org

(C) World Agroforestry Centre, 2014

Working Paper No. 178

The views expressed in this publication are those of the authors and not necessarily those of the World Agroforestry Centre.

Articles appearing in the Working Paper Series may be quoted or reproduced without charge, provided their source is acknowledged. 


\section{The authors}

Ian Dawson, Sammy Carsan, Steve Franzel, Roeland Kindt, Caleb Orwa and Ramni Jamnadass work for the World Agroforestry Centre (ICRAF). Paulo van Breugel, Lars Graudal and Jens-Peter Lillesø work for Forest \& Landscape Denmark, Department of Geosciences and Natural Resource

Management, University of Copenhagen, Rolighedsvej 23, 1958 Copenhagen, Denmark. 


\begin{abstract}
Agroforestry and livestock-keeping both have the potential to promote anthropogenic climate changeresilience, and understanding how they can support each other in this context is crucial. Here, we discuss relevant issues in East Africa, where recent agroforestry interventions to support livestockkeeping have included the planting of mostly-exotic tree-fodders, and where most parts of the region are expected to become drier in the next decades, although smaller areas may become wetter. Wider cultivation and improved management of fodder trees provides adaptation and mitigation opportunities in the region, but these are generally not well quantified and there are clear opportunities for increasing productivity and resilience through diversification, genetic improvement, improved farm-input delivery and better modelling of future scenarios. We relate, and illustrate with the example of current- and future-climate tree species distribution modelling, important areas for future research.
\end{abstract}

Keywords: calliandra dairy-production system; climate-smart agriculture; potential natural vegetation maps; tree-fodder production options 


\section{Acknowledgements}

The development of this paper was supported by the CGIAR research programme on Climate Change, Agriculture and Food Security (CCAFS). We thank colleagues including Jean Hanson, Henry Neufeldt, Jim Roshetko and Todd Rosenstock for providing information. 


\section{Contents}

1. Introduction

2. Livestock production systems in East Africa and the role of tree 2 fodder

2.1. Livestock production-systems maps

2.2. Agroforestry interventions to support livestock production

3. Climate change impacts and possible responses 3

3.1. Modelling future climate 3

3.2. Responding to climate change 3

3.3. Assumptions and uncertainties in mitigation 5

4. Diversifying tree-fodder production options 7

4.1. Sources of information $\quad 7$

$\begin{array}{ll}\text { 4.2. An example of priority setting } & 7\end{array}$

4.3. Exploiting intra- and inter-specific variation $\quad 8$

5. Biophysical responses of fodder trees to climate change 9

5.1. Migration, adaptation and translocation $\quad 9$

$\begin{array}{lr}\text { 5.2. The importance of delivery systems } & 10\end{array}$

$\begin{array}{lr}\text { 5.3. The use of 'plastic' trees } & 10\end{array}$

$\begin{array}{ll}\text { 5.4. Distribution modelling and vegetation maps } & 11\end{array}$

6. Adopting appropriate responses to climate change 12

6.1. Coping strategies and adopting new farming practices 12

6.2. Considerations in calliandra adoption $\quad 13$

$\begin{array}{ll}\text { 6.3. Lesson from elsewhere in Africa } & 14\end{array}$

$\begin{array}{ll}\text { 7. Areas for future research } & 14\end{array}$

7.1. Identifying options 14

$\begin{array}{lr}\text { 7.2. Coordinating and managing interventions } & 15\end{array}$

$\begin{array}{lr}\text { 7.3. Whole system analysis } & 15\end{array}$

$\begin{array}{ll}\text { 8. References } & 15\end{array}$ 
Figure 1. Some possible scenarios for fodder trees to contribute to climate change mitigation as dairy feed.

Figure 2. Modelled distributions of faidherbia (Faidherbia albida) under present and future climate in Ethiopia, Kenya, Malawi, Rwanda, Tanzania, Uganda and Zambia, based on a PNV approach.

\section{Tables}

Table 1. Some impacts of climate change on livestock production in East Africa and some possible agroforestry/tree-fodder responses.

Table 2. The number of tree and shrub species useful for fodder production, according to tree species guides for five East African countries.

\section{Boxes}

Box 1. Some other sources of information to support tree-fodder diversification. 


\section{Introduction}

Pan-tropically, agroforestry (www.worldagroforestry.org), livestock-keeping (www.ilri.org/) and the interactions between these practices are crucial for the livelihoods of rural communities (Garrity 2004, McDermott et al. 2010). Agroforestry practices are increasingly important as access to tree resources from natural forests and woodlands is lost through deforestation due to agricultural expansion (FAO 2010). At the same time, livestock production must deal with the increased competition between human food and animal feed, and the greater demand for animal products globally and the resulting environmental impacts, as human populations increase and their dietary preferences change (Delgado et al. 1999, Cassidy et al. 2013).

Comparing 1980 with the middle of the last decade, for example, the production and per capita consumption ${ }^{1}$ of meat, milk and eggs increased hugely in various parts of the world, most notably in East and Southeast Asia, and especially in China (FAO 2009). Most growth in meat production in the tropics over this period was through increased animal stocking, but notable increases in output per animal for milk and eggs were achieved in some regions, especially in East and Southeast Asia. By contrast, in sub-Saharan Africa over the same period, per capita consumption remained about the same over the region as a whole, while increases in efficiency observed in poultry and dairy farming observed elsewhere were not widely achieved (FAO 2009). In the last few years, however, increases in incomes in East Africa (World Bank 2014) are driving greater per capita meat and dairy consumption, as there is a strong positive correlation between incomes and the consumption of animal products (Ngigi 2005).

Agroforestry is recognised as an important component in climate-smart agriculture (defined as agriculture that brings humankind closer to safe operating spaces across spatial and temporal scales for food systems, in the context of climate change [Neufeldt et al. 2013]) for both its adaptation and mitigation roles (Thorlakson and Neufeldt 2012). One important feature is that trees and agroforestry systems provide a wide range of products and services that can substitute for each other and, in the right circumstances, can be produced synergistically. Similarly, livestock-keeping diversifies rural communities' production options and is often adapted to relatively marginal environments, which can promote climate-resilience (MacOpiyo et al. 2008, Thornton and Herrero 2008).

At the same time, livestock production globally contributes about $9 \%$ of total anthropogenic carbon dioxide $\left(\mathrm{CO}_{2}\right), 37 \%$ of methane $\left(\mathrm{CH}_{4}\right)$ and $65 \%$ of nitrous oxide $\left(\mathrm{N}_{2} \mathrm{O}\right)$ emissions (FAO 2009). Along the animal food chain, major sources of greenhouse gas (GHG) emissions include: land-use change to produce animal feed (e.g., $\mathrm{CO}_{2}$ emissions from cutting of forest for pasture and feeds crops in Latin America); other inputs into feed production (e.g., $\mathrm{CO}_{2}$ from fossil fuels used to manufacture chemical fertiliser for application to feed crops and to transport feeds); direct animal production (e.g., $\mathrm{CH}_{4}$ from enteric fermentation in ruminants); and manure emissions (e.g., $\mathrm{CH}_{4}, \mathrm{~N}_{2} \mathrm{O}$ and ammonia $\left[\mathrm{NH}_{3}\right]$ during storage, application and deposition). Ruminants such as cattle and buffalo are responsible for more GHG emissions than monogastric pigs and poultry (FAO 2009).

A response to livestock GHG emissions clearly requires that these be placed in the setting of the livelihood benefits livestock bring, especially for hundreds of millions of smallholders and pastoralists in low-income nations (Thornton and Herrero 2008). In this context, an understanding of how agroforestry practices and livestock-keeping respond to climate pressures, how they can support each other in the setting of anthropogenic climate change, and how altered practices for both can mitigate climate change, is clearly crucial. Here, we discuss these issues in the specific setting of agroforestry practices for tree fodder production in East Africa, a region where livestock-keeping is crucial for both the current well being and future climate-adaption of rural communities (McDermott et al. 2010), and where it has been suggested there is significant scope for improving current livestock practices

\footnotetext{
${ }^{1}$ In FAO (2009) the production comparison is based on the years 1980 and 2007, while the consumption comparison is based on the years 1980 and 2005.
} 
with low productivity (and often high unit-production emission intensities; Herrero et al. 2013; Opio et al. 2013). Feed shortages are common in the region, competition for resources results in conflicts and the costs of commercial animal feeds are often unaffordable.

\section{Livestock production systems in East Africa and the role of tree fodder}

\subsection{Livestock production-systems maps}

Cecchi et al. (2010) created a livestock production-systems map of East Africa (covering Djibouti, Eritrea, Kenya, Somalia, Uganda and parts of Ethiopia and Sudan) based on the proportion of farm earnings obtained from animals. Three categories of production system were defined: pastoral; agropastoral; and mixed farming. In the first two, mostly naturally-regenerating indigenous tree fodders among other plant feeds such as grasses are grazed by animals or (increasingly) are brought to enclosed stock in cut-and-carry systems (Roothaert et al. 2003). In the case of mixed farming, animals are generally enclosed and fed by cut-and-carried plant foods including crop residues, and other feeds such as concentrates; in such systems, the proportion of introduced animal breeds (and 'improved'local crosses) are higher than in pastoral and agro-pastoral systems (Franzel et al. 2014).

The map of Cecchi et al. (2010) corresponds well with an alternative livestock production-systems map for Africa derived by Thornton et al. (2002) largely from environmental data and 'the length of the growing period' (the LGP, a measure that compares predicted rainfall with the expected evapotranspiration rate to decide when through the year annual crops will grow). Thus, areas of low LGP value are dominated by pastoral systems and areas of high LGP value by mixed farming, with a narrow intermediate range of LGP values dominated by agro-pastoral systems. This correspondence is important because it provides support for the modelling of LGP under future climate as an approach to understand how the distribution of livestock production systems in East Africa will need to change over the next decades, and therefore how other components of agriculture, including feed production, will need to respond.

\subsection{Agroforestry interventions to support livestock production}

Agroforestry interventions to support livestock in East Africa have to date mostly focused on mixed faming systems sensu Cecchi et al. (2010). In the last three decades, new approaches have emerged involving the planting of mostly-exotic tree-fodders that are often grown along field boundaries, where they do not compete with crops, and along contours, where they help to limit soil erosion (Franzel et al. 2014). Such practices have recently been adopted by more than 200,000 small-scale dairy farmers in highland regions of Kenya, Uganda, Tanzania and Rwanda, with the Latin American calliandra (Calliandra calothyrsus, a leguminous species) being the most commonly planted fodder tree (Wambugu et al. 2011). Farmers use calliandra as a substitute for dairy meal or as a supplement to a basal diet including crop residues, Napier grass and natural grasses. One kilogram of dried calliandra leaf is estimated to contain the same amount of digestible protein as the same weight of dairy meal (Roothaert et al. 2003). For each dairy cow, a farmer needs approximately 500 calliandra trees to provide sufficient feed throughout the year, although the majority of farmers plant fewer than this. Normally, calliandra is ready for first pruning for fodder nine to 12 months after initial field establishment; pruning of each tree is then carried out four or five times a year, and the cut fodder carried to enclosed livestock for consumption.

Increases in dairy-cattle milk production achieved by adopting calliandra as a feed, in conjunction with several other important developments in the dairy sector (especially in the creation of more efficient market supply chains), have allowed smallholders to provide more milk to urban consumers and to raise extra revenue from milk sales; many smallholders also grow fodder trees to feed to their goats, with again significant positive impacts, including on milk yields (Place et al. 2009). The 
adoption of the calliandra technology has led to an increased demand for fodder-tree seed, which has resulted in the evolution of networks of small-scale seed dealers to support supply. Seed dealers not only improve their livelihoods through seed sales, but as they are themselves frequently dairy farmers, they can benefit twice (Wambugu et al. 2011).

In terms of its fodder production potential, however, seed dealers are handling suboptimal calliandra seed: the provenances of calliandra widely used for fodder in East Africa were introduced into the region in the 1970s and 1980s when the primary interest in the species was as a woodfuel, so little attention at the time was paid to fodder yield and quality (Mbora and Lillesø 2007). New seed introductions of superior fodder-producing calliandra types would therefore bring greater benefits for the region's dairy farmers (see more below on genetic variation in tree-fodder quality). Scherr and Franzel (2002) highlighted the benefits associated with investments in calliandra seed orchards when disseminating the fodder technology in new locations, and several of the same considerations apply when seeking to improve the quality of the calliandra seed in locations where the technology is already practiced. Interestingly, compared to other species, even the best performing provenances of calliandra are not of particularly high nutritional value, and its current adoption in East Africa has been more to do with its growth characteristics (ability to coppice, tolerance to frequent pruning, etc.) than its feed value, indicating the importance of tree-fodder species diversification in the region (see more below).

\section{Climate change impacts and possible responses}

\subsection{Modelling future climate}

Modelling of future climate is subject to uncertainties in the utility of different global climate models, in the limited ability to downscale to detailed geographic levels and in the various GHG trajectories that depend on the level of human mitigation action (Dawson et al. 2011). Under some predictions, large parts of East Africa are expected to become drier in the next decades, while smaller areas are anticipated to have higher annual rainfall, including parts of the highlands of Ethiopia, Kenya and Uganda (IPCC 2007). Modelling of changes in LGP to the year 2050 by Thornton et al. (2006) relate to these rainfall predictions in indicating reductions in LGP in some locations (drier regions) and increases in others (wetter regions). These predictions may however not fully account for the effects of anthropogenic warming of the Indian Ocean, which may cause greater drying of the East Africa region (Funk et al. 2008).

There is wide agreement that for the East Africa region as a whole more variable conditions are to be expected, with increased incidences of extreme weather events, and a general warming (IPCC 2007). Cognisance of different effects on climate in different parts of the East Africa region must be part of any appropriate response to climate change: although an adaptive strategy will likely primarily be concerned with the threats to agriculture and livestock production in increasingly dry regions, at the same time it is possible that there may be increased production opportunities for increasingly wet areas of more limited geographic extent.

\subsection{Responding to climate change}

In agro-pastoral systems where LGP is decreasing, cropping may decrease and farmers may resort to more extensive pastoral systems. In current pastoral systems, however, increased water shortages will likely worsen forage yields and make livestock-raising more vulnerable (MacOpiyo et al. 2008). Thornton and Herrero (2010a), for example, reported that an increase in drought frequency to a drought every three years rather than the historical every five years could decimate the herds of Kenya's pastoralists. On the other hand, if LGP increases in some locations, an intensification of livestock production systems (such as of the dairy farming system already described above) may be 
feasible at these sites. In such regions, maize yields, although subject to a general lowering in East Africa, would increase, providing more human food and animal feed (Jones and Thornton 2003, Shiferaw et al. 2012).

Possible adaptive responses to change include improved pasture management and a switch to alternative feed sources. Tree-fodders are considered an important response because trees with their deep root systems that can draw water from deep in the soil are more resilient to variability in weather patterns, and can provide fodder for longer than shallower-rooted plants in dry periods. In addition, there is a wide range of tree species that can be used for fodder, providing a number of options for possible feed-substitution (see next section). As fodder trees are more resistant to drought than annual crops, they can provide protein during the dry season when high-quality feed is otherwise scarce, which may be particularly important where the LGP (for crops) is decreasing (as described above). Trees also provide other functions important for climate adaptation, including shade for animals and, possibly, the provision of ethno-veterinary treatments to counter increased disease threats (such treatments are often relied on in areas with poor state veterinary services, especially in pastoral systems with poor infrastructure; Dharani et al. 2014). A number of impacts of climate change on livestock and possible agroforestry/tree-fodder responses for the East Africa region are summarised in Table 1.

Wider use of the right fodder trees in substitution for other feed options also provides mitigation opportunities through dietary intensification, tree carbon sequestration and savings through foregone concentrate and annual crop production and use (some possible scenarios are outlined in Fig. 1). Although (at the point of animal consumption) a high proportion of concentrate in the diet of ruminants results in low methane emissions as a proportion of energy intake when compared to fodder use, different fodders vary in their emission levels, and concentrate use must also take into account the probable higher emissions during production and delivery to farmers (O'Mara et al. 2008). 'Life cycle' or 'whole system' analysis of GHG balances (including feed-, animal-, landscape-, etc., emissions) is crucial when assessing the relative value of grain- and fodder-based feeds from an emissions perspective (Peters et al. 2012). Such assessments can be complex, however, and are relatively rare for livestock systems (de Boer et al. 2011; Opio et al. 2013).

Although detailed assessments are rare, the possible opportunities for livestock-related mitigation through improved pasture management have been quite widely described (e.g., Conant and Paustian 2002, Peters et al. 2012), which is in contrast to the opportunities for mitigation with agroforestrybased responses to animal production. Thornton and Herrero (2010b), however, considered both in modelling livestock-production mitigation scenarios for sub-Saharan Africa. Both future restoration of degraded rangelands and wider cultivation of the leucaena tree (Leucaena leucocephala, an alternative exotic fodder to calliandra [although one that is of only limited practical utility in East African highlands due to psyllid attack]) were considered. Both options had significant mitigation potential and both were better than the tested alternatives. In the case of leucaena cultivation, potential mitigation benefits were based on intensifying the diets of ruminants (allowing animal numbers to be reduced to meet a constant production demand) as well as carbon sequestration effects. 
Figure 1. Some possible scenarios for fodder trees to contribute to climate change mitigation as dairy feed.

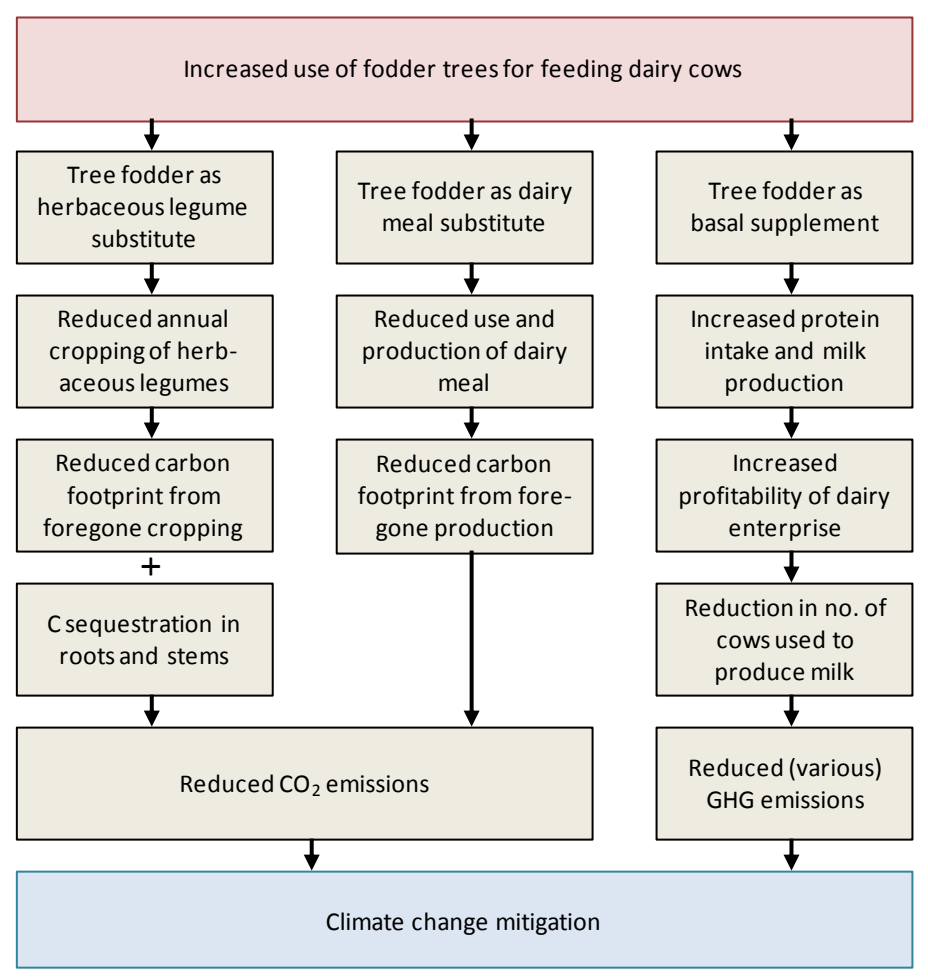

\subsection{Assumptions and uncertainties in mitigation}

As Thornton and Herrero (2010b) themselves state, their calculations represent theoretical scenarios with multiple (related and unrelated by them) assumptions. For example, increases in productivity may not reduce animal numbers to the extent expected if the demand for animal products increases as a result of lower prices. (See Kaimowitz and Angelsen 2008 for more on the [at first glance] counterintuitive effects of increasing productivity.) In addition, planting a fodder tree such as leucaena for its sequestration effects does not occur 'in a vacuum' in the farm landscape. Indeed, in smallholders' mixed farming systems tree planting may well be 'substitutional' rather than 'additional' (i.e., replacement of one tree by another in a fixed number of niches; Lengkeek et al. 2005). Net benefits will therefore depend on what has now been excluded. Trees planted and managed for fodder are also generally widely coppiced, so this reduces the potential (at least above ground) for sequestration. Thornton and Herrero's (2010b) calculations do, though, demonstrate the order of magnitude of mitigation benefits from fodder tree cultivation. 
Table 1. Some impacts of climate change on livestock production in East Africa and some possible agroforestry/tree-fodder responses (adapted from Thornton and Herrero 2008, with additional information from Herrero 2012, NRC 1981, Pilling and Hoffmann 2011, Thornton et al. 2008).

\section{Impact of climate change Possible agroforestry/tree-fodder responses ${ }^{\text {a }}$}

Decreases in feed quantity due to changing temperature and (reduced) rainfall and more variable weather (leading, e.g., to productivity losses, greater competition for food resources and water, and changing growth-suitability domains for particular feeds)
Reductions in feed quality under new climatic/weather conditions (e.g., due to lignification, leading to poor conversion)

Heightened physiological stress of animals by increased temperatures, drought (e.g., increases in heat-related mortality, lower productivity due to thermoregulation costs, reduced food intake, lower reproductive performance)

Increased prevalence of some animal diseases (e.g., of tickborne diseases in once cool, now warmer areas; of Rift Valley Fever virus in once dry, now wetter [?] areas)
- Change the composition of fodder tree species fed to animals, choosing from the very wide range of potential indigenous fodders available for use (NB, also change livestockspecies composition, e.g., more camels in very dry areas)

- Encourage natural regeneration of tree fodders that still produce good-quality, digestible feed under newly-prevailing environments

- Encourage natural regeneration of, and practice appropriate silviculture on, fodder and other trees to provide shade for livestock

- Encourage natural regeneration of fodder trees that are also of value for ethnoveterinary treatments
- Plant more drought-/temperature-/floodtolerant fodder tree species/provenances (e.g., with deep roots less sensitive to drought/flooding than other plants). (NB, also change livestock-breed composition/possible genetic improvement of livestock to withstand new stresses.) Plant tree fodders that grow well under new environmental conditions to fill productivity and seasonal gaps, including species with wider/atypical production phenologies. Establish trees on farms in ways that encourage deep root formation (e.g., via seed rather than cuttings)

- Increase overall farm productivity, including water use efficiency, through tree-based land management approaches (e.g., occupation of synergistic niches; protective shading to improve crop production; contour bunds to stop soil erosion and promote nutrient recycling)

- $\quad$ Plant tree fodders that are still able to produce good-quality, digestible feed under newly-prevailing environments

- $\quad$ Plant, and practice appropriate silviculture on, fodder and other trees to provide shade for livestock

- $\quad$ Plant fodder trees that are also of value for ethno-veterinary treatments

\footnotetext{
${ }^{a}$ Responses most relevant in pastoral and mixed farming livestock production systems sensu Cecchi et al. (2010). For agropastoral systems, both sets of responses may be relevant.
} 


\section{Diversifying tree-fodder production options}

\subsection{Sources of information}

Information that could support diversification in tree-fodder production in the East Africa region is available, but is limited in scope and quality, and is fragmented. A review of tree species guides for five East African countries (Eritrea, Ethiopia, Kenya, Tanzania and Uganda) conducted for this publication (Table 2) indicated 244 tree and shrub species across the region with some value as fodder. Many of these species also have possible alternative or additional uses such as shade and as ethnoveterinary medicines ( $54 \%$ and $18 \%$ of species, respectively), which illustrates supporting roles for livestock production (cf. Table 1). In addition, 38\% of listed fodder species were recorded to have value for soil conservation/improvement, which could support pasture and crop production and hence animal-feed provision. A review of the Agroforestree Database (AFTD) (www.worldagroforestry.org/resources/databases/agroforestree), which contains information on a wide range of products and services provided by more than 650 trees of importance to tropical smallholders, provided similar results (Dawson et al. 2014). The AFTD listed 295 trees (161 indigenous, 134 exotic) found in Africa that are noted for fodder production, with most species also having additional functions.

Tree species guides and the AFTD therefore demonstrate the diversity of tree and shrub species that can provide fodder, and the other products and services they can deliver that may support the resilience of production systems in the context of environmental change. Similarly, Dicko and Sikena (1992), for example, compiled a list of 124 fodder tree and shrub species found in dry tropical Africa, while Smith (1992) listed 56 trees and shrubs of known fodder value in humid parts of the continent. Other similar lists exist, while some other relevant databases including information on tree-fodders are described in Box 1. Efforts to link information in different databases to provide a more complete picture of fodder trees and their utility in Africa are underway (by one of the current authors, SC, among others). As or more important than lists of potentially useful species, however, is to understand current usage (and its efficiency, Leng 1997) and livestock-keepers' priorities, which will vary by location: many 'possible' fodder species may be of little interest to animal-keepers for a multitude of cultural and practical reasons, while understanding feed quality is also crucial (Sumberg 2002).

Narrowing down attention to a manageable number of species for research purposes, based on the right criteria for prioritisation and a critical approach to selection, is therefore an important issue.

\subsection{An example of priority setting}

In an example of priority setting, farmer-surveys in three agro-ecological zones in Kenya with different rainfall- and animal production-system- profiles revealed that the three most preferred 'local' species in the sub-humid zone $(1300 \mathrm{~mm}$ rainfall, where improved stall-fed dairy animals predominate) were Triumfetta tomentosa, Commiphora zimmermanii and Bridelia micrantha, in the medium zone (rainfall $959 \mathrm{~mm}$ ) were Aspilia mossambicensis, Lantana camara (actually an exotic rather than indigenous species) and Grewia tembensis, and in the dry zone (rainfall $775 \mathrm{~mm}$, communally-grazed, local-breed animals most common) were Melia volkensii, Crotalaria goodiiformis and A. mossambicensis (Roothaert and Franzel 2001). Nearly all of these species regenerated naturally rather than being planted, although Central Kenyan farmers have shown some interest in actively cultivating indigenous fodder trees: clearly, the opportunities for intervention are different depending on whether the development of planting programmes for these species can be considered a viable option (e.g., to develop supplemental 'protein banks' in agro-pastoral systems) or whether focusing on better managing natural regeneration is a preferred approach (Roothaert et al. 2003). (Further research on farmers' fodder preferences is currently ongoing by SC and others.) 
Table 2. The number of tree and shrub species useful for fodder production, according to tree species guides for five East African countries. Both indigenous and exotic tree species are included, although most species listed by guides are of indigenous origin. Of species that are described as useful for fodder, other uses according to guides are also given (ordered by the highest total mention across all five countries).

\begin{tabular}{|c|c|c|c|c|c|c|}
\hline Use & Eritrea & Ethiopia & Kenya & Tanzania & Uganda & $\begin{array}{l}\text { All } 5 \text { countries } \\
\text { (\% of fodder) }\end{array}$ \\
\hline Fodder & 113 & 111 & 165 & 115 & 101 & $244(-)$ \\
\hline Firewood & 92 & 102 & 143 & 108 & 90 & $198(81)$ \\
\hline Medicine/stimulant & 76 & 77 & 137 & 95 & 73 & $168(69)$ \\
\hline Timber & 63 & 68 & 98 & 79 & 69 & $133(55)$ \\
\hline Shade & 56 & 70 & 108 & 78 & 72 & $131(54)$ \\
\hline Food (fruit, nuts) & 52 & 56 & 88 & 59 & 54 & $113(46)$ \\
\hline Soil conservation/improvement & 49 & 59 & 66 & 59 & 50 & $93(38)$ \\
\hline Nitrogen fixation & 27 & 31 & 39 & 38 & 31 & $55(23)$ \\
\hline Veterinary medicine & 27 & 25 & 42 & 26 & 22 & $44(18)$ \\
\hline
\end{tabular}

A species may not have been mentioned for a given use by all countries to be included in the table (it must only be present in that country). Sources of information: Eritrea, Bein et al. (1996); Ethiopia, Bekele-Tesemma (2007); Kenya, Maundu and Tengnas (2005); Tanzania, Mbuya et al. (1994); Uganda, Katende et al. (1995). Data compiled by RK and CO.

Box 1. Some other sources of information to support tree-fodder diversification

Tropical Forages: an Interactive Selection Tool (www.tropicalforages.info/)

This database provides information on 187 plant species, including trees and shrubs, of potential as forages in the tropics. The database is not only a list of species with information on uses, ecology, agronomy, feed value and production potential, but a tool that allows the selection of possibly appropriate species for cultivation at a given location, based on factors such as intended uses (in addition to animal food), annual rainfall, altitude and length of the dry season.

The Sub-Saharan Africa Feed Composition Database (http://192.156.137.110/ssafeed/)

This database provides information on the nutritive value of more than 20,000 samples of more than 5,000 different livestock feeds from 15 countries in sub-Saharan Africa, including information on 216 fodder trees and shrubs. Samples were analysed at the Animal Nutrition Laboratory of the International Livestock Research Institute in Addis Ababa, Ethiopia. The database is intended to help design scientifically-based, best-cost rations for meat, dairy and draught animals for small-scale African farmers.

Feedipedia: Animal Feed Resources Information System (www.feedipedia.org/)

This database provides information on 753 animal feeds, including on 53 fodder trees. Some information is given on the distribution, management and feed utility of tree-fodders, as well as feeding recommendations for different animal categories. The primary objective of Feedipedia is to provide the latest scientific information to identify, characterise and properly use feed resources to develop the livestock sector, especially where local feed resources are currently under-utilised.

\subsection{Exploiting intra- and inter-specific variation}

In theory, potential for improved productivity not only comes from the use of the right species, but in exploiting the genetic variation in fodder production characteristics that occur within species.

Calliandra, for example, demonstrates large differences in leaf production and leaf digestibility among 
provenances that could be very usefully exploited to improve value (Chamberlain 2001, Tuwei et al. 2003), but as noted above little attention was given to these features during introductions to the East Africa region. Genetic variation in fodder production and quality for most native African trees and shrubs has not been widely studied, although there are exceptions. For example, significant provenance differences in leaf protein and the readily digestible fraction of organic matter were observed on testing the native African shrub combretum (Combretum aculeatum) (Fernandez-Rivera and Weber 2000). Other African examples where production, digestibility, etc., have been studied at an intra-specific level include Sesbania sesban (Heering 1995, Heering et al. 1996a, b) and in Erythrina species (Larbi et al. 1996).

These studies indicate that both species- and genetic-level selection (for fodder quantity and quality, but also for ease of establishment, ability to prune, seasonality, browse- and coppice-tolerance, toxicity, etc., Shelton 2000) could play an important role in the more optimal cultivation of fodder trees and shrubs. Required are species and provenances that show both good growth characteristics and high feed value, and that are easy to source and supply for planting. Under climate change, more attention could be paid to selecting species and cultivars that reduce nitrous oxide and methane emissions from ruminants through achieving a better balance between water soluble carbohydrate and crude protein, and by altering the content of tannins that complex with soluble proteins and render them insoluble in the rumen yet release them under the acidic conditions found in the small intestine, reducing bloat and increasing amino acid absorption (Abberton et al. 2008).

\section{Biophysical responses of fodder trees to climate change}

\subsection{Migration, adaptation and translocation}

Initial tree-fodder-based responses to climate change involve compositional adjustments among different species, in which natural regeneration (in more extensive systems) and/or planting (in more intensive systems) of well-performing fodders under newly-prevailing conditions are encouraged (Table 1). At the individual species level, responses to environmental change include possible natural migration (through natural seed dispersal) to new climatically-suitable locations for growth, and genetic adaption to change at existing locations (Dawson et al. 2011). Many naturally-regenerating fodder trees are relatively common in landscapes, are prolific seeders and are precocious (producing seed only a few years after establishment), which may facilitate both natural migration and local adaptation. This is especially so in extensive production systems, where response-constraints such as human land-use boundaries that prevent migration, and weeding that limits natural regeneration, are low (although animal grazing of tree seedlings during regeneration may be a limiting factor).

In the case of planted fodder trees (e.g., in mixed farming systems), an alternative response under the control of farmers is 'facilitated translocation' (Dawson et al. 2011), which involves the human movement of seed to sites expected to experience analogous environmental conditions in future years. For some tree-fodder legumes with selective associations with nitrogen-fixing bacteria, translocation of the microorganism may also be important (the climate-change response of the microorganism itself also needs to be considered). To engage in such translocation activities requires that the environmental limits of species (assessed through observing current distributions and through field trials of climate-related diversity) are well understood, which is often not the case (Aitken et al. 2008).

Certainly, more field trials are needed on indigenous fodder trees, which pay attention to the physiological mechanisms underlying responses to climatic change (assessing, e.g., drought tolerance, the phenology [date of initiation and duration] of leaf and fruit [including animal-edible pods, for legumes] production, water use efficiency and the ability to withstand water-logging). Particularly important may be the responses of trees to climate change at the level of establishment (production of tree seedlings in the nursery, planting-out in the field and/or early responses of seedlings during natural regeneration). An understanding of the trait of reverse phenology, as observed for the African 
tree faidherbia (Faidherbia albida), whose leaves and pods are grazed directly by animals or cut-andcarried in pastoral and agro-pastoral systems, is also important. Faidherbia unusually produces leaves in the dry season and the complex reverse phenology trait, which varies by environment (e.g., the level of water stress), is under partial genetic control (Barnes and Fagg 2003).

Practical cases where climate change considerations have been taken into account in tree variety- or provenance-level site matching (rather than species-site matching) in agroforestry systems are to date limited, but one case is provided by African prosopis (Prosopis africana), which among other uses is fed (the leaves and pods) to livestock. Based on field trials in the Sahel measuring growth and survival (among other characteristics) in relation to rainfall patterns across seed collection sites, Weber et al. (2008) recommended that germplasm transfers of the species should only be undertaken in a single direction, from drier to (currently) wetter zones; such a strategy was adopted in the Sahel in an International Fund for Agricultural Development (IFAD) agroforestry project. In regions where future climate remains highly uncertain, an emphasis on matching to a more limiting (drier) scenario is more risk-averse (i.e., reducing year-to-year variation in production), but average production may be lower with such a strategy (cf. the case, for crops, of using 'drought-resistant' maize in East Africa, as quoted by Thorlakson and Neufeldt 2012).

\subsection{The importance of delivery systems}

Responses to climate change that involve the facilitated translocation of appropriately-adapted tree germplasm must consider how farmers gain access to this material. However, tree germplasm delivery systems for African smallholders currently do not work well. 'Centralised' models of delivery based around 'formal' institutions such as national tree seed centres (NTSCs) have generally proven ineffective because of the high costs involved in reaching widely-dispersed clients. 'Informal' local commercial tree seed collectors and nursery operators that have lower operating costs are in a better position to sustainably meet farmers' tree seed and seedling needs (see the example of calliandra above). Often, however, such suppliers have been discriminated against by development agencysupported subsidies to formal suppliers and NGOs to provide 'free seed' to farmers, which distorts incipient markets, and the current regulatory framework (Lillesø et al. 2011). Institutional innovations that lead to more sustained and more efficient public support for decentralised networks of tree seed suppliers, and for the establishment and effective use of seed orchards of superior quality genetic material, are required (Lillesø et al. 2014). NGOs should support local entrepreneurial seed suppliers and tree nurseries with the business training they need to operate profitably and sustainably, rather than competing with them in the provision of planting material.

In the specific setting of climate change, both formal and informal germplasm suppliers have crucial roles in supporting adaptation, and action is required to better support their interaction in this context: NTSCs are needed to coordinate germplasm flows at macro-and meso-scales based on climatic predictions (including country-to-country exchange of germplasm between current-future analogue sites, when required; Koskela et al. 2009); and networks of local entrepreneurs are required to actually reach farmers with tree seed and seedlings at the meso- to micro-scale (Dawson et al. 2011).

\subsection{The use of 'plastic' trees}

Another possible response to climate change for planted fodder trees is to promote the use of 'plastic' species and varietal types/provenances (Gienapp et al. 2008), i.e., those trees with flexible morphologies and physiologies that grow at least reasonably well under a range of different environmental stresses without any requirement for genetic change. This may be especially useful when greater variation in weather conditions is anticipated, such as combinations of increased drought and flooding. Some species of Leucaena - which originated in Latin America but are now distributed and used as exotic fodders worldwide - may fit this category (Hughes 1998). Such species can be strongly competitive (e.g., for water resources), however, which may displace other trees and the 
production of crops (Osman-Elasha 2009). The possibilities for catastrophic shock also still remain (due, e.g., to insect attacks that may become more prevalent under climate change; e.g., Loo et al. 2011). A better approach could be to first gain an understanding of the climatic requirements of a wider range of indigenous fodder trees and then promote the more climate-resilient ones.

\subsection{Distribution modelling and vegetation maps}

For East Africa, an important first step in determining appropriate indigenous tree-fodders for specific locations under climate change could be to model existing and potential future geographic distributions based on the high-resolution potential natural vegetation (PNV) maps that are available for the region (van Breugel et al. 2011). The use of PNVs - rather than point location data, which are often limited for trees (but see more below on farm inventories) - for distribution modelling is currently being tested in East Africa for a range of tree species important for fodder provision and other purposes ( $\mathrm{PvB}, \mathrm{RK}, \mathrm{LG}$ and J-PBL from the current paper are involved). An example of present-future modelling for faidherbia based on PNVs, covering parts of East Africa and extending into southern Africa, is given in Figure 2. Early results of such modelling suggest important changes in the suitability domains of indigenous fodder trees in East Africa that will need to be considered in planning (e.g., it helps to understand which species will be 'lost' or 'gained' in particular locations under climate change).

An alternative approach for distribution modelling is to make use of detailed farm-tree inventory data collected in the East Africa region (e.g., Kehlenbeck et al. 2011, Lengkeek et al. 2005 for Kenya). In this case, data can also be used to model the potential future distributions of exotic trees such as calliandra and leucaena, since locations of both indigenous and exotic trees were captured in farm surveys. On these maps, information on LGP and tree phenology should be superimposed to assist planning. As noted above, modelling of future climatic conditions is subject to several uncertainties and these of course apply in determining future tree species distributions; there are additional uncertainties in modelling mixed-species agroforestry systems (Luedeling et al. 2014). Modelling potential distributions however allows an assessment of risks and the planning of contingencies. 
Figure 2. Modelled distributions of faidherbia (Faidherbia albida) under present and future climate in Ethiopia, Kenya, Malawi, Rwanda, Tanzania, Uganda and Zambia, based on a PNV approach. The future prediction shown (for the 2080s) is based on climate change scenario A2 and global circulation model HCCPR HADCM3.

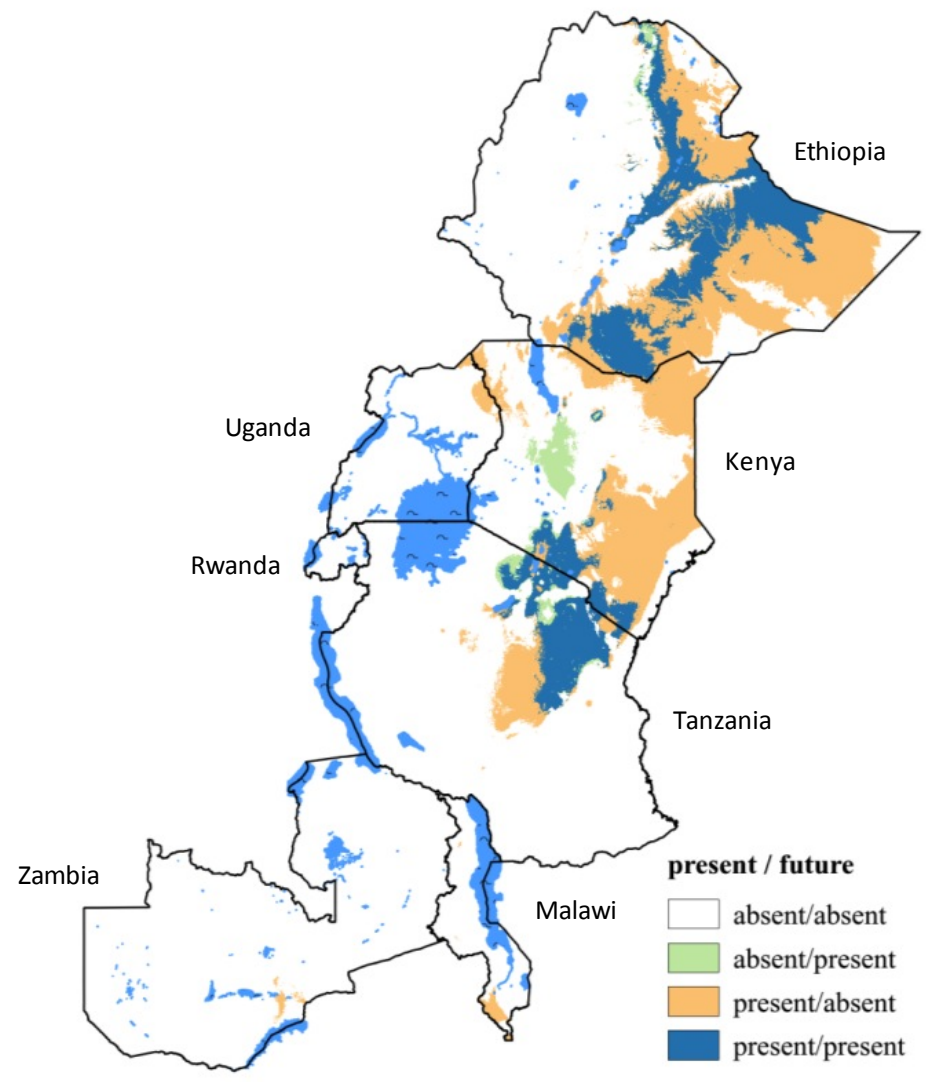

Modelling is based on PNVs as proxies for the overall distribution of faidherbia, masking PNVs where the distribution appears to be largely determined by edaphic factors. An ensemble approach to modelling was employed and a weighted average of predictions from the five best models applied to determine likely distributions. For further information on modelling methods, see van Breugel et al. (2011); additional information will be provided in forthcoming publications by PVB and others. It should be noted that the modelling approach applied here is experimental: validation, and refining utility, is the subject of ongoing research (compare, e.g., the current-climate faidherbia map shown here with Barnes and Fagg 2003).

\section{Adopting appropriate responses to climate change}

\subsection{Coping strategies and adopting new farming practices}

Devising tree-fodder-related responses to climate change in East Africa requires an understanding of how, why and when farmers in the region adopt agroforestry interventions, and what effects the adoption of such practices have on climate-resilience. Thorlakson and Neufeldt (2012) assessed the coping strategies of farmers to environmental shocks (drought and flooding) in two locations in Nyando District in western Kenya in 2009 and 2010. 'Treatment' farmers had been previously involved in ICRAF agroforestry development projects (involving training and the distribution of tree planting material, in 2006 and 2008), while 'control' farmers had not. Overall, treatment farmers adopted fewer detrimental coping strategies to deal with extreme conditions, although the sale of possessions or livestock was a common coping strategy for both sets of farmers (for 59\% of treatment farmers and $51 \%$ of control farmers, i.e., sales, if anything, more likely for the treatment group; our calculations based on aggregating given data). Superficially, agroforestry options would therefore not 
appear to support farm animal numbers after weather shocks. The picture is however complex, as treatment farmers that had practiced agroforestry for longer also had higher stocking levels, so the two sets of farmers were not responding from the same position. In addition, the time between the agroforestry interventions and the environmental shocks that led to animal sales was relatively short, meaning that the benefits (for example) from tree-fodder may have not yet been very significant. More widely, Thorlakson and Neufeldt (2012) noted that smallholders in western Kenya see resilience to environmental stressors as coming through improved incomes, and planting trees for sale (fuelwood, timber, fruit, etc.) is therefore an important component of a tree-based climate-change adaptation strategy.

In another study covering a range of agro-ecological systems in Ethiopia, Kenya, Tanzania and Uganda, Kristjanson et al. (2012) explored the relationship between food security and farmer innovation in the context of changing demographic, economic, and ecological conditions including climate variability. Based on a survey of 700 farm households, a strong positive relationship was demonstrated between food security and the adoption of new farming practices over the previous decade, but it was not possible to determine whether this was because innovative households are more food-secure as a result of innovation, or if more food-secure households are better placed to subsequently innovate. In one of the surveyed locations (Lushoto District in Tanzania, where the keeping of dairy cattle is common), the introduction of cut-and-carry livestock-feeding systems and the growing of fodder crops were new practices adopted by many farmers ( $65 \%$ and $50 \%$ of surveyed farm households for the two practices, respectively). Both practices had also been adopted in the previous decade by more than $10 \%$ of surveyed farmers in two other locations (Lower Nyando Basin in Kenya and Kagera Basin in Uganda). How often these practices involved tree-fodders (rather than, e.g., grasses), however, was not recorded. Although Kristjanson et al. (2012) found that many of the surveyed households across the region were practising agroforestry, the overall level of tree planting by farmers in the year prior to the survey was determined to have been low (at only one site, Kagera Basin, had more than $10 \%$ of surveyed farm households planted more than 50 trees in the previous year). The authors of the study indicated that there is a need to understand why there has not been wider uptake of agroforestry, and whether this is due to the initial investment required before benefits are received from tree planting.

\subsection{Considerations in calliandra adoption}

The case of calliandra fodder production described above represents a technology that has apparently enjoyed quite wide adoption by East African smallholders in mixed farming systems. The success that has been achieved (with $>200,000$ smallholders) has been attributed to the use of a combination of extension approaches, including the involvement of NGOs concerned with promoting the dairy sector in East Africa, the support of 'expert' dissemination facilitators to extension providers, and the involvement of 'master disseminator' farmer adopters, each of whom has spread the technology to many additional farmers (Franzel and Wambugu 2007). Crucial, of course, has been the presence of a market for milk (Franzel et al. 2014). Considering the magnitude of the smallholder dairy sector in East Africa as a whole, however, the level of adoption of the calliandra technology is less than $10 \%$, with great variation in the number of fodder trees planted by individual farmers. Indeed, as a cautionary note, Sumberg (2002) (although not considering the calliandra example) indicated that the utility of fodder legume (planting) in Africa has often been over-played, and suggested a more critical analysis is required in which greater attention is given to fundamental (agro-climatic, social, economic and cultural) system properties in design specification.

In order to realise greater impact with calliandra, Franzel et al. (2014) indicated the need for better quality fodder tree seed sources delivered to farmers by more optimal input-supply systems, the importance of being able to recommend a wider range of tree-fodders (species and provenances) for planting in high altitude and semi-arid zones, and the requirement for greater extension support. The last is important because the raising of seedlings, field planting, pruning, etc., of exotic fodder trees is relatively knowledge intensive. 


\subsection{Lesson from elsewhere in Africa}

Although the contexts are different and care is required in extrapolation, lessons for adoption in East African agro-pastoral livestock production systems may come from experiences in the Sahel. There, farmer-managed natural regeneration of trees and shrubs (FMNR), particularly of faidherbia and other legumes, supports soil fertility improvement (and hence staple crop production; Bayala et al. 2011, Place and Binam 2013) and the provision of animal fodder. Since 1985 in Niger alone, FMNR practices, supported by a policy shift to award tree tenure to farmers, has led to the 'regreening' of approximately 5 million hectares (Sendzimir et al. 2011). Place and Binam (2013), in a preliminary analysis covering Burkina Faso, Mali, Niger and Senegal, observed a statistically significant positive correlation between the total number of household trees and the number of oxen held, and between the number of small- and medium-diameter trees and the number of sheep and goats held. Just over $50 \%$ of 480 surveyed households in Niger were reported to use faidherbia leaves and pods as livestock feed; these sources of fodder were reported by rural households to be available for three months in the year (other important tree fodders were reported to be available for longer, e.g., Piliostigma reticulatum, used by $18 \%$ of surveyed households in Niger, for 4.5 months).

It should be possible to apply relevant implementation approaches as learnt in the Sahel to East Africa with the advent of the new Regional Program on Food and Water in the Sahel and the Horn of Africa, which will support the development of integrated and intensified dryland agricultural systems in countries including Ethiopia and Kenya (ICRAF 2012). At the very least, experiences in the Sahel indicate that a few relatively straightforward interventions in drylands landscape management can sometimes have significant impacts on production systems involving crops and livestock. Similar impacts are required in East Africa based on the scale of change desired in the region (Herrero et al. 2013).

\section{Areas for future research}

Apart from general research on the utility and adoption of agroforestry technologies for responding to climate change and other production challenges in East Africa, we suggest the following issues should be given priority in the context of tree fodder use, livestock, adaptation and mitigation.

\subsection{Identifying options}

- The identification is required of fodder trees species and provenances for planting in mixed and agro-pastoral farming systems that combine the good features of calliandra (in terms of management) with better feed characteristics. ICRAF holds a wide range of provenances of a number of trees species in its seed genebank that could be suitable candidates, and these should be prioritised and tested.

- As large animals may be more sensitive to climate change-related temperature increases than small ones, with climate warming there may be a shift to small-animal production (Seo and Mendelsohn 2007). How do we account for such a shift in a feed-production strategy?

- Only limited data are available on how the phenology of fodder trees will respond to climate change. Research is required to understand, in particular, any changes in phenology that would make production systems more vulnerable to dry-season animal-feed shortages, and suitable alternatives for fodder production.

- In order to understand which tree-fodders are appropriate for promotion in particular locations in East Africa under future climate, there is a need to develop present-day and future suitability maps for a wider range of indigenous and exotic species. These then need to be related to production maps for alternative plant-feed sources, and to the future extrapolation domains of 
different livestock types that will also alter with climate change and that have different feed requirements.

\subsection{Coordinating and managing interventions}

- As livestock production systems sensu Cecchi et al. (2010) and/or Thornton et al. $(2002,2006)$ alter under climate change, how do we best coordinate the various required parallel interventions (e.g., changes in feed composition and management, changes in animal composition and management) to optimise production under new conditions?

- How can work on fodder trees fit with other ongoing initiatives on fodder production in East Africa, for example, the promotion of 'dual-purpose' sweet potato (vines for animal feed and tubers for human food), which has promise for smallholders in mixed crop-livestock systems (Claessens et al. 2009)? Fodder shrubs should be promoted as part of a suite of interventions to improve feed availability, to offer farmers a full range of options to choose from in addressing their feed problems. Tools such as the Feeds Assessment Tool (FEAST; www.ilri.org/feast) are available to assess current feed availability and gaps, and to plan ways to improve availability.

- How can agroforestry respond to any increased opportunities for dairy production that climate change may bring in restricted parts of East Africa where rainfall may increase? These areas (in highlands) may be well geographically separated from each other, which may make the provision of inputs in intervention more complex.

- In scenarios such as that presented by the smallholder calliandra-feeding dairy approach, how best can the increased commercialisation of milk supply be used to efficiently drive 'climate-smart' agroforestry approaches including the production and feeding of superior-quality tree-fodders? Do climate-change-responses provide opportunities for new influxes of higher-quality calliandra germplasm and/or of other fodder trees? Enhanced links between NTSCs and small-scale entrepreneurial tree seed and seedling suppliers will be required to respond to climate change; engaging in such responses may present opportunities for wholesale quality improvements in farmers' germplasm inputs for addressing wider production challenges (human population growth, soil fertility depletion, etc.). Developing appropriate responses requires the testing of new institutional relationships between public (e.g., NTSC) and private (e.g., small-scale seed supplier) actors (Lillesø et al. 2014).

\subsection{Whole system analysis}

- Whole system GHG analysis of the smallholder calliandra-feeding dairy approach to assess the fodder tree contribution to mitigation strategies is essential. (For leguminous tree species such as calliandra, a consideration of $\mathrm{N}$ fluxes through fixation may be an important element [Rosenstock et al. 2014].) In particular it would be useful in such analyses to compare fodder trees with alternative ways to provide protein, such as the feeding of concentrate. In whole system analysis, the relative contributions of fodder tree cultivation to fixing carbon above- and below-ground needs assessment in the context of tree management strategies such as coppicing.

\section{References}

Abberton MT, Marshall AH, Humphreys MW, Macduff JH (2008) Genetic improvement of forage crops for climate change mitigation. In: Rowlinson P, Steele M, Nefzaoui A (eds.) Livestock and Global Climate Change. Proceedings, International Conference in Hammamet, 17-20 May 2008. British Society of Animal Science, Cambridge University Press, Cambridge, UK, pp. 48-51. 
Aitken SN, Yeaman S, Holliday JA, Wang T, Curtis-McLane S (2008) Adaptation, migration or extirpation: climate change outcomes for tree populations. Evolutionary Applications, 1, 95-111.

Barnes RD, Fagg CW (2003) Faidherbia albida: monograph and annotated bibliography. Tropical Forestry Papers No. 41. Oxford Forestry Institute, Oxford, UK.

Bayala J, Kalinganire A, Tchoundjeu Z, Sinclair F, Garrity D (2011) Conservation agriculture with trees in the West African Sahel - a review. ICRAF Occasional Paper No. 14. The World Agroforestry Centre, Nairobi, Kenya.

Bein E, Habte B, Jaber A, Birnie A, Tengnas B (1996) Useful trees and shrubs in Eritrea: identification, propagation and management for agricultural and pastoral communities. Technical Handbook Series No. 12. Regional Soil Conservation Unit, Nairobi, Kenya.

Bekele-Tesemma A (2007) Useful trees and shrubs of Ethiopia: identification, propagation and management for 17 agroclimatic zones. Technical Manual Series No. 6, RELMA in ICRAF Project. The World Agroforestry Centre, Nairobi, Kenya.

Cassidy ES, West PC, Gerber JS, Foley JA (2013) Redefining agricultural yields: from tonnes to people nourished per hectare. Environmental Research Letters, 8, 034015, doi:10.1088/17489326/8/3/034015

Cecchi G, Wint W, Shaw A, Marletta A, Mattioli R, Robinson T (2010) Geographic distribution and environmental characterization of livestock production systems in Eastern Africa. Agriculture, Ecosystems and Environment, 135, 98-110.

Chamberlain JR (ed.) (2001) Calliandra calothyrsus: an agroforestry tree for the humid tropics. Tropical Forestry Papers No. 40. Oxford Forestry Institute, Oxford, UK.

Claessens L, Stoorvogel JJ, Antle JM (2009) Ex ante assessment of dual-purpose sweet potato in the crop-livestock system of western Kenya: A minimum-data approach. Agricultural Systems, 99, 13 22.

Conant RT, Paustian K (2002) Potential soil carbon sequestration in overgrazed grassland ecosystems. Global Biogeochemical Cycles, 16, 1143, doi: 10.1029/2001GB001661

Dawson IK, Leakey R, Place F, Clement CR, Weber JC, Cornelius JP, Roshetko JM, Tchoundjeu Z, Kalinganire A, Masters E, et al. (2014) Trees, tree genetic resources and the livelihoods of rural communities in the tropics. Thematic Study for the State of the World's Forest Genetic Resources. Food and Agriculture Organization of the United Nations, Rome, Italy.

Dawson IK, Vinceti B, Weber JC, Neufeldt H, Russell J, Lengkeek AG, Kalinganire A, Kindt R, Lillesø J-PB, Roshetko J, et al. (2011) Climate change and tree genetic resource management: maintaining and enhancing the productivity and value of smallholder tropical agroforestry landscapes. A review. Agroforestry Systems, 81, 67-78.

de Boer IJM, Cederberg C, Eady S, Gollnow S, Kristensen T, Macleod M, Meul M, Nemecek T, Phong LT, Thoma G, et al. (2011) Greenhouse gas mitigation in animal production: towards an integrated life cycle sustainability assessment. Current Opinion in Environmental Sustainability, 3, 423-431.

Delgado C, Rosegrant M, Steinfeld H, Ehui S, Courbois C (1999) Livestock to 2020: the next food revolution. Food, Agriculture, and the Environment Discussion Paper No. 28. The International Food Policy Research Institute, Washington DC, USA. 
Dharani N, Yenesew A, Ermais B, Tuei B, Jamnadass R (ed. Dawson IK) (2014) Traditional Ethnoveterinary Medicine in East Africa: a Manual on the Use of Medicinal Plants. The World Agroforestry Centre, Nairobi, Kenya (in press).

Dicko MS, Sikena LK (1992) Fodder trees and shrubs in range and farming systems in dry tropical Africa. In: Speedy A, Pugliese P-L (eds.) Legume Trees and Other Fodder Trees as Protein Sources for Livestock. Proceedings of the FAO Expert Consultation Held at the Malaysian Agricultural Research and Development Institute (MARDI), Kuala Lumpur, Malaysia, 14-18 October 1991. Food and Agriculture Organization of the United Nations, Rome, Italy, pp. 27-41.

FAO (2009) The State of Food and Agriculture: Livestock in the Balance. Food and Agriculture Organization of the United Nations, Rome, Italy.

FAO (2010) Global forest resources assessment 2010. FAO Forestry Paper No. 163. Food and Agriculture Organization of the United Nations, Rome, Italy.

Fernandez-Rivera S, Weber JC (2000) Genetic variation in fodder quality traits of Combretum aculeatum foliage. In: Gintzburger G, Bounejmate M, Agola C, Mossi K (eds.) Production and Utilization of Multi-purpose Fodder Shrubs and Trees in West Asia, North Africa and the Sahel. The International Center for Agricultural Research in the Dry Areas, Aleppo, Syria and the International Livestock Research Institute, Nairobi, Kenya, pp. 42-46.

Franzel S, Carsan S, Lukuyu B, Sinja J, Wambugu C (2014) Fodder trees for improving livestock productivity and smallholder livelihoods in Africa. Current Opinion in Environmental Sustainability, 6, 98-103.

Franzel S, Wambugu C (2007) The uptake of fodder shrubs among smallholders in East Africa: key elements that facilitate widespread adoption. In: Hare MD, Wongpichet K (eds.) Forages: a Pathway to Prosperity for Smallholder Farmers. Proceedings of an International Symposium. Faculty of Agriculture, Ubon Ratchathani University, Thailand, pp. 203-222.

Funk C, Dettinger MD, Michaelsen JC, Verdin JP, Brown ME, Barlow M, Hoell A (2008) Warming of the Indian Ocean threatens eastern and southern African food security but could be mitigated by agricultural development. Proceedings of the National Academy of Sciences of the USA, 105, 1108111086.

Garrity DP (2004) Agroforestry and the achievement of the Millennium Development Goals. Agroforestry Systems, 61, 5-17.

Gienapp P, Teplitsky C, Alho JS, Mills JA, Merila J (2008) Climate change and evolution: disentangling environmental and genetic responses. Molecular Ecology, 17, 167-178.

Heering JH (1995) The effect of cutting height and frequency on the forage, wood and seed production of six Sesbania sesban accessions. Agroforestry Systems, 30, 341-350.

Heering JH, Nokoe S, Mohammed J (1996) The classification of a Sesbania sesban (ssp. sesban) collection. II. Agronomic attributes and their relation to biomass estimation. Tropical Grasslands, 30, 215-222.

Heering H, Reed JD, Hanson J (1996) Differences in Sesbania sesban accessions in relation to their phenolic concentration and HPLC fingerprints. Journal of the Science of Food and Agriculture, 71, 92-98.

Herrero M (2012) Livestock. In: Thornton P, Cramer L (eds.) Impacts of climate change on the agricultural and aquatic systems and natural resources within the CGIAR's mandate. CCAFS 
Working Paper No. 23. CGIAR Research Program on Climate Change, Agriculture and Food Security (CCAFS), Copenhagen, Denmark, pp. 86-95.

Herrero M, Havlík P, Valin H, Notenbaert A, Rufino MC, Thornton PK, Blümmel M, Weiss F, Grace D, Obersteiner M (2013) Biomass use, production, feed efficiencies, and greenhouse gas emissions from global livestock systems. Proceedings of the National Academy of Sciences of the USA, 110, 20888-20893.

Hughes CE (1998) Leucaena: a genetic resources handbook. Tropical Forestry Papers No 37. Oxford Forestry Institute, Oxford, UK.

ICRAF (2012) Regional Program on Food and Water in the Sahel and the Horn of Africa: Regenerating Dryland Farming Systems through Creating an EverGreen Agriculture. Project Development Document. The World Agroforestry Centre, Nairobi, Kenya.

IPCC (2007) Climate change 2007. The Fourth Assessment Report of the Intergovernmental Panel on Climate Change. Cambridge University Press, Cambridge, UK.

Jones PG, Thornton PK (2003) The potential impacts of climate change on maize production in Africa and Latin America in 2055. Global Environmental Change, 13, 51-59.

Kaimowitz D, Angelsen A (2008) Will livestock intensification help save Latin America's tropical forests? Journal of Sustainable Forestry, 27, 6-24.

Katende A, Birnie A, Tengnas B (1995) Useful trees and shrubs for Uganda: identification and management for agricultural and pastoral communities. Technical Handbook Series No. 10. Regional Soil Conservation Unit, Nairobi, Kenya.

Kehlenbeck K, Kindt R, Sinclair FL, Simons AJ, Jamnadass R (2011) Exotic tree species displace indigenous ones on farms at intermediate altitudes around Mount Kenya. Agroforestry Systems, 83, 133-147.

Koskela J, Vinceti B, Dvorak W, Bush D, Dawson I, Loo J, Kjaer ED, Navarro C, Padolina C, Bordács S, et al. (2009) The use and movement of forest genetic resources for food and agriculture. Background Study Paper No. 44. The Commission on Genetic Resources for Food and Agriculture, Food and Agriculture Organization of the United Nations, Rome, Italy.

Kristjanson P, Neufeldt H, Gassner A, Mango J, Kyazze FB, Desta S, Sayula G, Thiede B, Förch W, Thornton PK, et al. (2012) Are food insecure smallholder households making changes in their farming practices? Evidence from East Africa. Food Security, 4, 381-397.

Larbi A, Kurdi IO, Said AN, Hanson J (1996) Classification of Erythrina provenances by rumen degradation characteristics of dry matter and nitrogen. Agroforestry Systems, 33, 153-163.

Leng RA (1997) Tree foliage in ruminant nutrition. FAO Animal Production and Health Paper No. 139. Food and Agriculture Organization of the United Nations, Rome, Italy.

Lengkeek AG, Kindt R, van der Maesen LJG, Simons AJ, van Oijen DCC (2005) Tree density and germplasm source in agroforestry ecosystems in Meru, Mount Kenya. Genetic Resources and Crop Evolution, 52, 709-721.

Luedeling E, Kindt R, Huth NI, Koenig K (2014) Agroforestry systems in a changing climate challenges in projecting future performance. Current Opinion in Environmental Sustainability, 6, 1-7. 
Lillesø J-PB, Graudal L, Moestrup S, Kjær ED, Kindt R, Mbora A, Dawson IK, Muriuki J, Ræbild A, Jamnadass R (2011) Innovation in input supply systems in smallholder agroforestry: seed sources, supply chains and support systems. Agroforestry Systems, 83, 347-359.

Lillesø J-PB, Roshetko J, Harwood C, Derero A, Graudal L, Dawson IK, Kindt R, Weber J, Degrande A, Moestrup S, et al. (2014) How can good quality tree planting material be delivered to smallholders? Reviewing the experiences of the last two decades. Development Policy Review (under review).

Loo J, Fady B, Dawson I, Vinceti B, Baldinelli G (2011) Climate change and forest genetic resources: state of knowledge, risks and opportunities. Background Study Paper No. 56. The Commission on Genetic Resources for Food and Agriculture, Food and Agriculture Organization of the United Nations, Rome, Italy.

MacOpiyo L, Angerer J, Dyke P, Kaitho R (2008) Experiences on mitigation or adaptation needs in Ethiopia and East African rangelands. In: Rowlinson P, Steele M, Nefzaoui A (eds.) Livestock and Global Climate Change. Proceedings, International Conference in Hammamet, 17-20 May 2008. British Society of Animal Science, Cambridge University Press, Cambridge, UK, pp. 64-67.

Maundu P, Tengnas B (eds.) (2005) Useful trees and shrubs for Kenya. RELMA Technical Handbook No. 35. The World Agroforestry Centre, Nairobi, Kenya.

Mbora A, Lillesø J-PB (2007) Sources of tree seed and vegetative propagation of trees around Mt. Kenya. Development and Environment 9-2007. Forest \& Landscape Denmark, University of Copenhagen, Copenhagen, Denmark.

Mbuya LP, Msanga HP, Ruffo CK, Birnie A, Tengnas B (1994) Useful trees and shrubs for Tanzania: identification, propagation and management for agricultural and pastoral communities. Technical Handbook Series No. 6. Regional Soil Conservation Unit, Nairobi, Kenya.

McDermott JJ, Staal SJ, Freeman HA, Herrero M, Van de Steeg JA (2010) Sustaining intensification of smallholder livestock systems in the tropics. Livestock Science, 130, 95-109.

Neufeldt H, Jahn M, Campbell BM, Beddington JR, DeClerck F, De Pinto A, Gulledge J, Hellin J, Herrero M, Jarvis A, et al. (2013) Beyond climate-smart agriculture: toward safe operating spaces for global food systems. Agriculture \& Food Security, 2, 12, www.agricultureandfoodsecurity.com/content $/ 2 / 1 / 12$

Ngigi M (2005) The case of smallholder dairying in Eastern Africa. Environment and Production Technology Division Discussion Paper No. 131. The International Food Policy Research Institute, Washington DC, USA.

NRC (1981) Effect of Environment on Nutrient Requirements of Domestic Animals. Subcommittee on Environmental Stress, National Research Council (NRC). National Academy Press, Washington DC, USA.

O’Mara FP, Beauchemin KA, Kreuzer M, McAllister TA (2008) Reduction of greenhouse gas emissions of ruminants through nutritional strategies. In: Rowlinson P, Steele M, Nefzaoui A (eds.) Livestock and Global Climate Change. Proceedings, International Conference in Hammamet, 17-20 May 2008. British Society of Animal Science, Cambridge University Press, Cambridge, UK, pp. 4043.

Opio C, Gerber P, Mottet A, Falcucci A, Tempio G, MacLeod M, Vellinga T, Henderson B, Steinfeld H (2013) Greenhouse Gas Emissions from Ruminant Supply Chains - A Global Life Cycle Assessment. Food and Agriculture Organization of the United Nations, Rome, Italy. 
Osman-Elasha B (2009) Climate change impacts, adaptation and links to sustainable development in Africa. Unasylva, 60, 12-16.

Peters M, Rao I, Fisher M, Subbarao G, Martens S, Herrero M, van der Hoek R, Schultze-Kraft R, Miles J, Castro A, et al. (2012) Tropical forage-based systems to mitigate greenhouse gas emissions. In: Hershey C, Neate P (eds.) Eco-efficiency: from Vision to Reality. Issues in Tropical Agriculture Series. The International Centre for Tropical Agriculture, Cali, Colombia, pp. 171-190.

Pilling D, Hoffmann I (2011) Climate change and animal genetic resources for food and agriculture: state of knowledge, risks and opportunities. Background Study Paper No. 53. The Commission on Genetic Resources for Food and Agriculture, Food and Agriculture Organization of the United Nations, Rome, Italy.

Place F, Binam JN (2013) Economic Impacts of Farmer Managed Natural Regeneration in the Sahel: End of Project Technical Report for the Free University Amsterdam and IFAD. The World Agroforestry Centre, Nairobi, Kenya.

Place F, Roothaert R, Maina L, Franzel S, Sinja J and Wanjiku J (2009) The impact of fodder trees on milk production and income among smallholder dairy farmers in East Africa and the role of research. ICRAF Occasional Paper No. 12. The World Agroforestry Centre, Nairobi, Kenya.

Roothaert RL, Franzel S (2001) Farmers' preferences and use of local fodder trees and shrubs in Kenya. Agroforestry Systems, 52, 239-252.

Roothaert R, Franzel S, Kiura M (2003) On-farm evaluation of fodder trees and shrubs preferred by farmers in central Kenya. Experimental Agriculture, 39, 423-440.

Rosenstock TS, Tully KL, Arias-Navarro C, Neufeldt H, Butterbach-Bahl K, Verchot LV (2014) Agroforestry with N2-fixing trees: sustainable development's friend or foe? Current Opinion in Environmental Sustainability, 6, 15-21.

Scherr SJ, Franzel S (2002) Promoting new agroforestry technologies: policy lessons from on-farm research. In Franzel S, Scherr SJ (eds.) Trees on the Farm: Assessing the Adoption Potential of Agroforestry Practices in Africa. CABI Publishing, Wallingford, UK, pp. 145-168.

Sendzimir J, Reij CP, Magnuszewski P (2011) Rebuilding resilience in the Sahel: regreening in the Maradi and Zinder regions of Niger. Ecology and Society, 16, www.ecologyandsociety.org/vol16/iss3/art1/

Seo SN, Mendelsohn R (2007) Climate change impacts on animal husbandry in Africa: a Ricardian analysis. World Bank Policy Research Working Paper No. 4261. The World Bank, Washington DC, USA.

Shelton HM (2000) Tropical forage tree legumes in agroforestry systems. Unasylva, 51, 25-32.

Shiferaw B, Hellin J, Gerard B, Braun H-J, Stirling C, Cairns J, Reynolds M, Prasanna BM, Gbegbelegbe S, Ortiz-Monasterio I, et al. (2012) Maize. In: Thornton P, Cramer L (eds.) Impacts of climate change on the agricultural and aquatic systems and natural resources within the CGIAR's mandate. CCAFS Working Paper No. 23. CGIAR Research Program on Climate Change, Agriculture and Food Security (CCAFS), Copenhagen, Denmark, pp. 96-105.

Smith OB (1992) Fodder trees and shrubs in range and farming systems in tropical humid Africa. In: Speedy A, Pugliese P-L (eds.) Legume Trees and Other Fodder Trees as Protein Sources for Livestock. Proceedings of the FAO Expert Consultation Held at the Malaysian Agricultural Research 
and Development Institute (MARDI), Kuala Lumpur, Malaysia, 14-18 October 1991. Food and Agriculture Organization of the United Nations, Rome, Italy, pp. 43-59.

Sumberg J (2002) The logic of fodder legumes in Africa. Food Policy, 27, 285-300.

Thorlakson T, Neufeldt H (2012) Reducing subsistence farmers' vulnerability to climate change: evaluating the potential contributions of agroforestry in western Kenya. Agriculture \& Food Security, 1,15 , www.agricultureandfoodsecurity.com/content/1/1/15

Thornton P, Herrero M (2008) Priority livestock development issues linked to climate change. In: Rowlinson P, Steele M, Nefzaoui A (eds.) Livestock and Global Climate Change. Proceedings, International Conference in Hammamet, 17-20 May 2008. British Society of Animal Science, Cambridge University Press, Cambridge, UK, pp. 21-24.

Thornton PK, Herrero M (2010a) The inter-linkages between rapid growth in livestock production, climate change, and the impacts on water resources, land use, and deforestation. World Bank Policy Research Working Paper No. 5178. The World Bank, Washington DC, USA.

Thornton PK, Herrero M (2010b) Potential for reduced methane and carbon dioxide emissions from livestock and pasture management in the tropics. Proceedings of the National Academy of Sciences of the USA, 46, 19667-19672.

Thornton PK, Jones PG, Owiyo T, Kruska RL, Herrero M, Kristjanson P, Notenbaert A, Bekele N, Omolo A (with further contributions) (2006) Mapping Climate Vulnerability and Poverty in Africa. Report to the Department for International Development. The International Livestock Research Institute, Nairobi, Kenya.

Thornton PK, Kruska RL, Henninger N, Kristjanson PM, Reid RS, Atieno F, Odero A, Ndegwa T (2002) Mapping Poverty and Livestock in the Developing World. The International Livestock Research Institute, Nairobi, Kenya.

Thornton P K, Van de Steeg J, Notenbaert A and Herrero M (2008) The livestock-climate-poverty nexus: A discussion paper on ILRI research in relation to climate change. Discussion Paper No. 11. The International Livestock Research Institute, Nairobi, Kenya.

Tuwei PK, Kang'ara JNN, Mueller-Harvey I, Poole J, Ngugi FK, Stewart JL (2003) Factors affecting biomass production and nutritive value of Calliandra calothyrsus leaf as fodder for ruminants. Journal of Agricultural Science, 141, 113-127.

van Breugel P, Kindt R, Lillesø JB, Bingham M, Demissew S, Dudley C, Friis I, Gachathi F, Kalema J, Mbago F, et al. (2011) VECEA: potential natural vegetation of Eastern Africa (Ethiopia, Kenya, Malawi, Rwanda, Tanzania, Uganda and Zambia). Volume 7: projected distributions of potential natural vegetation types and two important agroforestry species (Prunus africana and Warburgia ugandensis) for six possible future climates. Forest \& Landscape Working Paper No. 69. Forest \& Landscape, University of Copenhagen, Copenhagen, Denmark.

Wambugu C, Place F, Franzel S (2011) Research, development and scaling up the adoption of fodder shrub innovations in East Africa. International Journal of Agricultural Sustainability, 9, 100-109.

Weber JC, Larwanou M, Abasse TA, Kalinganire A (2008) Growth and survival of Prosopis africana provenances related to rainfall gradients in the West African Sahel. Forest Ecology and Management $256,585-592$.

World Bank (2014) Global Economic Prospects January 2014. The World Bank, Washington DC, USA. 


\section{Working Paper Series}

2012

141. Fortalecimiento de capacidades para la gestión del Santuario Nacional Pampa Hermosa: Construyendo las bases para un manejo adaptativo para el desarrollo local. Memorias del Proyect

142. Understanding rural institutional strengthening: A cross-level policy and institutional framework for sustainable development in Kenya

143. Climate change vulnerability of agroforestry

144. Rapid assessment of the inner Niger delta of Mali

145. Designing an incentive program to reduce on-farm deforestation in the East Usambara Mountains, Tanzania

146. Extent of adoption of conservation agriculture and agroforestry in Africa: the case of Tanzania, Kenya, Ghana, and Zambia

147. Policy incentives for scaling up conservation agriculture with trees in Africa: the case of Tanzania, Kenya, Ghana and Zambia

148. Commoditized or co-invested environmental services? Rewards for environmental services scheme: River Care program Way Besai watershed, Lampung, Indonesia

149. Assessment of the headwaters of the Blue Nile in Ethiopia

150. Assessment of the uThukela Watershed, Kwazaulu

151. Assessment of the Oum Zessar Watershed of Tunisia

152. Assessment of the Ruwenzori Mountains in Uganda

153. History of agroforestry research and development in Viet Nam. Analysis of research, opportunities and gaps

154. REDD+ in Indonesia: a historical perspective

155. Agroforestry and Forestry in Sulawesi series: Livelihood strategies and land use system dynamics in South Sulawesi

156. Agroforestry and Forestry in Sulawesi series: Livelihood strategies and land use system dynamics in Southeast Sulawesi.

157. Agroforestry and Forestry in Sulawesi series: Profitability and land-use systems in South and Southeast Sulawesi.

158. Agroforestry and Forestry in Sulawesi series: Gender, livelihoods and land in South and Southeast Sulawesi

159. Agroforestry and Forestry in Sulawesi series: Agroforestry extension needs at the community level in AgFor project sites in South and Southeast Sulawesi, Indonesia

160. Agroforestry and Forestry in Sulawesi series: Rapid market appraisal of agricultural, plantation and forestry commodities in South and Southeast Sulawesi

2013

161. Diagnosis of farming systems in the Agroforestry for Livelihoods of Smallholder farmers in Northwestern Viet Nam project

162. Ecosystem vulnerability to climate change: a literature review

163. Local capacity for implementing payments for environmental services schemes: lessons from the RUPES project in northeastern Viet Nam

164. Seri Agroforestri dan Kehutanan di Sulawesi: Agroforestry dan Kehutanan di Sulawesi: Strategi mata pencaharian dan dinamika sistem penggunaan lahan di Sulawesi Selatan

165. Seri Agroforestri dan Kehutanan di Sulawesi: Mata pencaharian dan dinamika sistem penggunaan lahan di Sulawesi Tenggara

166. Seri Agroforestri dan Kehutanan di Sulawesi: Profitabilitas sistem penggunaan lahan di Sulawesi Selatan dan Sulawesi Tenggara

167. Seri Agroforestri dan Kehutanan di Sulawesi: Gender, mata pencarian dan lahan di Sulawesi Selatan dan Sulawesi Tenggara

168. Seri Agroforestri dan Kehutanan di Sulawesi: Kebutuhan penyuluhan agroforestri pada tingkat masyarakat di lokasi proyek AgFor di Sulawesi Selatan dan Tenggara, Indonesia

169. Seri Agroforestri dan Kehutanan di Sulawesi: Laporan hasil penilaian cepat untuk komoditas pertanian, perkebunan dan kehutanan di Sulawesi Selatan dan Tenggara

170. Agroforestry, food and nutritional security

171. Stakeholder Preferences over Rewards for Ecosystem Services: Implications for a REDD+ Benefit Distribution System in Viet Nam

172. Payments for ecosystem services schemes: project-level insights on benefits for ecosystems and the rural poor

173. Good practices for smallholder teak plantations: keys to success

174. Market analysis of selected agroforestry products in the Vision for Change Project intervention Zone, Côte d'Ivoire

175. Rattan futures in Katingan: why do smallholders abandon or keep their gardens in Indonesia's 'rattan district'?

176. Management along a gradient: the case of Southeast Sulawesi's cacao production landscapes

2014

177. Are trees buffering ecosystems and livelihoods in agricultural landscapes of the Lower Mekong Basin? Consequences for climate-change adaptation 
The World Agroforestry Centre is an autonomous, non-profit research organization whose vision is a rural transformation in the developing world as smallholder households increase their use of trees in agricultural landscapes to improve food security, nutrition, income, health, shelter, social cohesion, energy resources and environmental sustainability. The Centre generates science-based knowledge about the diverse roles that trees play in agricultural landscapes, and uses its research to advance policies and practices, and their implementation that benefit the poor and the environment. It aims to ensure that all this is achieved by enhancing the quality of its science work, increasing operational efficiency, building and maintaining strong partnerships, accelerating the use and impact of its research, and promoting greater cohesion, interdependence and alignment within the organization.

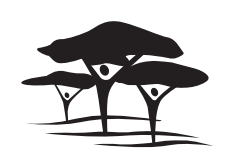

United Nations Avenue, Gigiri • PO Box 30677 • Nairobi, $00100 \cdot$ Kenya Telephone: +254207224000 or via USA +1 6508336645 Fax: +254207224001 or via USA +1 6508336646 Email: worldagroforestry@cgiar.org •www.worldagroforestry.org 